\title{
Conversation with Sri Lankan Director Dharmasena Pathiraja
}

\author{
By Brandon Wee \\ Fall 2004 Issue of KINEMA \\ ONE LEAGUE OF SOCIAL CONSCIOUSNESS: CONVERSATION WITH SRI LANKAN
DIRECTOR DHARMASENA PATHIRAJA
}

He has been referred to as a "rebel with a cause," an "enfant terrible of the '70s, and is widely recognised as the pioneer of Sri Lankan cinema's "second revolution." However, from his speech and writings, one gathers Dharmasena Pathiraja is more interested in re-examining the values that underpin such popular labels than to let his work be framed by mere posturing. If Lester James Peries has been credited with the establishment of an indigenous Sinhala cinema coinciding with Sri Lanka's political, social and cultural revolution during the mid-1950s, and whose works were categorised as "art films" dissimilar to those of mainstream filmmaking, Dharmasena Pathiraja's arrival on the scene in the 1970s would redefine a socially conscious Other to Peries' gaze on "bourgeois idealism." For Pathiraja, critical engagement would be his "alternative."

Sri Lanka in the early '70s was a particularly tumultuous period for social change, but it was this chapter that produced a generation of artists who were thirsty to challenge the existing social order. Reacting to the failure of the country's successive socialist governments in 1956, 1962 and 1970 to deliver the benefits of the post-independence revolution and the rise of Sinhala populism, the Janatha Vimukthi Peramuna (JVP) or People's Liberation Front, led by educated but unemployed youths, mounted an armed insurrection to overthrow the government in April 1971. In days, the rebellion was crushed, leaving scores of people dead. Impassioned by a desire to say something about his era, as well as by the institutional incentives that came his way, Pathiraja emerged to become one of Sri Lanka's best-known filmmakers of the time.

In April 2003, at the invitation of the Sri Lanka-based Asian Film Centre (AFC), the $16^{\text {th }}$ Singapore International Film Festival (SIFF) hosted the first-ever Dharmasena Pathiraja retrospective outside Sri Lanka. Five of his eight features were screened: One League of Sky (1974), Ponmani (1977), The Wasps Are Here (1978), On The Run (1980) and Old Soldier (1981). Pathiraja's most recent film, Some Day In The Future (2001), was an official selection in Singapore the previous year. Absent were Coming of Age (1977) and Whirl Wind (1994).

In the monograph An Incomplete Sentence: The Films of Dharmasena Pathiraja, published by the AFC (ed. Robert Crusz and Ashley Ratnavibhushana) to accompany the occasion of the Singapore retrospective, Pathiraja, in conversation with Sivamohan Sumathy, discusses his filmmaking at length with academic and anecdotal rigour. "In a lifetime of work, the corpus is a work by itself; a text. Like a book, a line, a sentence. A historical line moving from film to film, text to text," he muses before acknowledging the spring of his proclivity. Recalls Pathiraja: "Youth and film - you see - there is a touch of romance there."

Illuminating the impetus for his debut feature One League Of Sky, a poignant account of the anxieties and ideals of youth, Pathiraja reflects with empathy:

What intrigued me, and something that continues to haunt my films is the idea of people from the outskirts pouring into the city. In our country, particularly at that time - the '60s and '70s - Colombo was beginning to form, develop an identity. This identity was given shape by those who were moving in from outside. It was this search of those people that kind of matched mine as well. The characters are individualized enough to act, to have agency. For instance, there is no romance plot in the structure of the film. But there is romance. The overall story is the romantic yearning of the youth to belong within the cityscape.

Pathiraja regards his films as social commentaries; they are critical of attitudes wrought by the social and political circumstances of the time but are also sympathetic to the humanistic dilemmas that beset them. On The Run - his favourite - is set against the backdrop of an emerging Colombo and is uncompromising in its observation of the recklessness of youth. Likewise in One League Of Sky, whose young adults at its core are soon ripped from their firmaments of bliss and willed to survive in a corrupting urban environment, to devastating consequences. In the intriguing The Wasps Are Here, Pathiraja tackles the politics of community 
by laying bare a series of urban-rural tensions amid the contrasting tranquillity of a fishing village in Kalpitiya, on Sri Lanka's west coast; on the same wavelength, Ponmani is a powerful study of the familial institution, depicting an upper caste girl's elopement with a lower caste man and her indifference in the face of the consequences, much to the censure of her family and people.

But it is Pathiraja's treatment of the subject matter in Old Soldier that stands as his most humanist work. The ruminative story takes place during Sri Lanka's Independence Day on its eve, the holiday and the day after, and involves the participation of four oppressed souls: a World War II veteran, a prostitute, her thieving pimp and a clerk who have chosen the base of a tree as their asylum from the spectacle of pageantry. An unusual tension hangs through the film as their disaffections with the construct of "nationhood" become apparent and compellingly articulated, with the soldier's reminisces providing much of the story's heart.

In this interview, Pathiraja, a Senior Lecturer in Film Studies at the University of Colombo, shares the memories of his formative years as a student besotted by cinema, his ensuing trials as an artist and filmmaker, and the problems that continue to plague filmmakers in Sri Lanka.

Brandon Wee: In Sri Lanka you have been called a "rebel with a cause." How do you feel about this label?

Dharmasena Pathiraja: It's really metaphorical. One should not think of the artist as a rebel who is going to bring about objective change. The rebel is within you. So you rebel not against the world but against yourself. In Asian societies particularly, one struggles to capture a reality in rebellious terms. One recreates realities through a rebellious search for freedom of expression from the tired old forms, the familiar ways of capturing reality, and the experiences of social reality. This rebellion has to come from within one by way of confronting familiar truths.

\section{How did you get into filmmaking?}

My fascination for moving images began at 14 when I saw my first film, but we were forbidden to go to the cinema because our families saw it as a corrupting medium. It was not a well recognised medium of art but seen as entertainment. When I saw my first film, it was like seeing a magic show. I was so excited then I didn't know how to express myself; I was fascinated. I started off as a writer: I wrote short stories, poems, drama and read about literature but the fascination with the moving image stayed with me throughout. Then as a student in university, I read about cinema, got highly involved with the film society movement and watched many films, especially from outside Sri Lanka. We didn't have any institution to teach film but I finally got involved with filmmaking while working with some senior technicians. It was like a lifelong desire that came true. I thought it was my medium; me. I could not find a better way of capturing the reality around me. At the same time I associated closely with the Left movement in Sri Lanka. I was never a party member of any political movement but I sympathised intimately with some of the organisations. The political protests expressed though the Left programmes combined and prodded me toward a protest medium in film. I don't think this was a deliberate attempt but an undercurrent. The Left opened up challenges not only in the political field but also in the area of form. For me, that kind of courage to think beyond the confinements of the familiar was an important part of the Left tradition, especially where my films are concerned.

You insert political elements at critical moments in your films, such as One League Of Sky's grating, "victory to the oppressed masses" street demonstrations. There's also the character of Weere in The Wasps Are Here, who is not only personified as the film's prevailing conscience but who has a central scene where he exhorts the evils of exploitation.

There is a subversion of this man's character in the film. He's a Left-oriented man, but you can see some kind of romanticism in the way he has come to the village to talk about Marxism and exploitation to the people. This attitudinising was part of a generation who was quite sincere and "objectively" correct, yet were somewhat out of touch with the realities of the people, their material conditions, power, and even their powerlessness. We have had a series of youth insurrections in Sri Lanka, but none have been able to mobilise people through their Marxist vision. These people were alienated from the society they wished to deliver from exploitation. In that scene I try to remark on that subtly: this character holds forth from a platform in the village but as he moves off the next moment, we see an empty square. In another part of the village a police post is being set up. This character is not caricaturised. He is, as you say, the conscience of the film; 
a narrator, but it is more than that too.

The Wasps Are Here underscores the tensions between fishing village folk and city dwellers, and we are told "wasps" refer to city people - by implication, nasty urban insects. Yet the fish merchant, Anton, is equally parasitical. So is the title intended as an ironic double-entendre? Yes, this also because the wasps are already there. Symbolically, the film is about exploitation. Even the relationship between the male characters and Helen, the central female figure, is exploitative. There is a sexual theme running through the film.

Why did audiences not take well to On The Run when it was released?

Some people said it was ahead of its time but I didn't believe that. The film has a very simple theme but they didn't see it as simple. People look for hidden meanings instead of what is already there and have preconceived notions of what a film should be like. However, a lot of people talk about the film now. They like it very much - even those from my generation - and I think there is an understanding of its style now that wasn't there before. I like this film because the lead character Chandare also came from the village to the city, like me. I come from a village near central hill country.

Did the abortion issue in On The Run command attention?

Yes. There is a lot of talk about abortion, whether one should do it or not. It is a controversial topic in Sri Lanka even today. The abortion subject was central in the film and I used it to penetrate the traditions of the village and city. I wanted to show the rootlessness and alienation of the people who come from the villages, particularly the displacement of young people and their inability to resolve their problems. They're always on the run, looking for something in life.

Is this a commentary on the naïveté of youth?

Yes, but it is more than that. It is about how everybody is dislocated in the city, the village or wherever they live in this country. It is social dislocation tied up with personal dislocation.

\section{What was controversial about Ponmani?}

This was the first time a Sinhala director directed a Tamil language film. It was made with my friends when I was teaching at the university in Jaffna city. At the beginning there was a campaign against the film and the controversy emerged because the main issues we discussed were the dowry and the caste problems. In the film, Ponmani, an upper caste Vellala girl elopes with a lower caste Catholic boy from the fishing community. In practice this would be likened to a crime. The other thing was that audiences were too used to the formulaic films of the southern Indian industry and so the familiar signifiers were not present here. They saw their cities, villages, roads and people who looked like them and these representations made them uncomfortable.

\section{How strong was this campaign?}

Not so strong, but people coming to watch the film were approached by others and told not to, and to leave. It happened to me. After the fourth day of release in a theatre in Jaffna, I went to see the film but was told not to watch it. They didn't know I was the director at the time. Later, they stopped showing the film in the theatres.

There is a feminist undercurrent to your films. You are sympathetic towards women even though they may be powerless, and the emotional accent on them is evident.

Women are central in a way because the narrative or the disjuncture in the narrative gets routed through them. They are focal points. It is a particular reality of women that is represented there.

Is there a reason why you have understated the emotions, particularly at the end of Ponmani? It captures the bottled up nature of their lives, particularly the lives of Ponmani's family. These people are together but separated all the same. They are severely alienated from society; given their high caste and yet economically failing wealth, they are at the mercy of their own prejudices, bonds and conservatism.

What is the status of Sri Lankan cinema?

It is quite productive. I think we can call filmmakers like Asoka Handagama and Prasanna Vithanage the third generation. They're courageous, creative and have amazing talent. But all of us are suffering from a lack of finances. We can't think what our next films will be because if you don't have any kind of finance, 
it means you can't think about anything. You can't even begin to conceive a new film. Two years ago, the National Film Corporation funded 40 productions but did not continue the following year because they said, "No, we don't have money and we didn't recover the money we had spent." So who is going to finance independent ventures? If the state can't come up with money to finance films, especially for this younger generation, then I think there is no hope.

Are you saying the state doesn't value culture?

Not in the way we think of culture. I think the situation is fast deteriorating. The main thing is this ethnic war, which has been around for decades. I don't even think the government has money for its own survival. Prices are going up steeply by the day and you see the suffering of people, so I don't think they have enough resources to spend on cultural activities. The other thing is, the cost of making a film today is very high. Not a single film can recover the costs and if one cannot recover the costs one will be in bad shape.

How hungry is the Sri Lankan audience for locally made films?

Not that much. But it's highly competitive because society has changed rapidly over the last two decades. This did not lead to improved standards in the arts and culture but it did pave the way for other social changes. In 1971 we had a youth uprising and people were scared to even go out of their houses. Back then, film meant family entertainment but now, because of this economic depression, the whole family can't go to the cinema since it will cost a lot of money. Then in 1983, during the anti-Tamil riots, Sinhala hooligans driven by other interested parties, including powerful sections of the government, set fire to about 50 theatres all over. And during the war, theatres in Jaffna and the northern peninsula were destroyed. So now we have a very limited number of cinemas and that's not enough. But even within Sri Lanka, films don't travel much.

What you have described seems at odds with the kind of content that is being produced, such as Asoka Handagama's Flying With One Wing (2002), which deals the lives of transgendered persons. Are contemporary Sri Lankan filmmakers tackling similar issues?

Yes, they are really sensitive to these types of social and ideological issues relating to marginality. People welcome that, but you also see a lot of resistance, a kind of backlash. People also take on moralist positions. For Asoka's film, there were a lot of these so-called moralists opposing it, not to mention the campaign against it. But people still received the film very well. It showed to packed houses.

\section{What is your future?}

Looking back at my career as a filmmaker, I can't understand how I survived. I didn't earn any money from these films although I have had my job teaching at the university for the last 36 years. That was how I survived but actually, I am uncertain about filmmaking. This is a feeling I have had from the very beginning. My first feature, One League of Sky, didn't make money. I had to wait more than two years for another producer to arrive before starting my second production. After that I had to wait again. There was never this continual process during my career.

Will restored prints of your films be available one day?

Yes. Ashley Ratnavibhushana of the Asian Film Centre, who was the one behind this venture, wants to preserve these films and he's planning to find some finances to get them restored.

\section{What about DVDs?}

I think so too, because until the Singapore International Film Festival's retrospective, my films were not exposed internationally. When I went to UCLA in Los Angeles in 1994 and screened On The Run, the audience there was surprised at its style. The professor of film and television studies asked me, "Why didn't you send out this film at the time you produced it?" I said the simple answer was I didn't have money for subtitling. The other thing was I didn't have any kind of international connections. That's the reason why my films didn't get proper exposure internationally. Unfortunately, the SIFF screenings were in BETA format and were very bad copies. I did not have a single reprint of a film.

[This interview has also been published in Senses of Cinema online] 


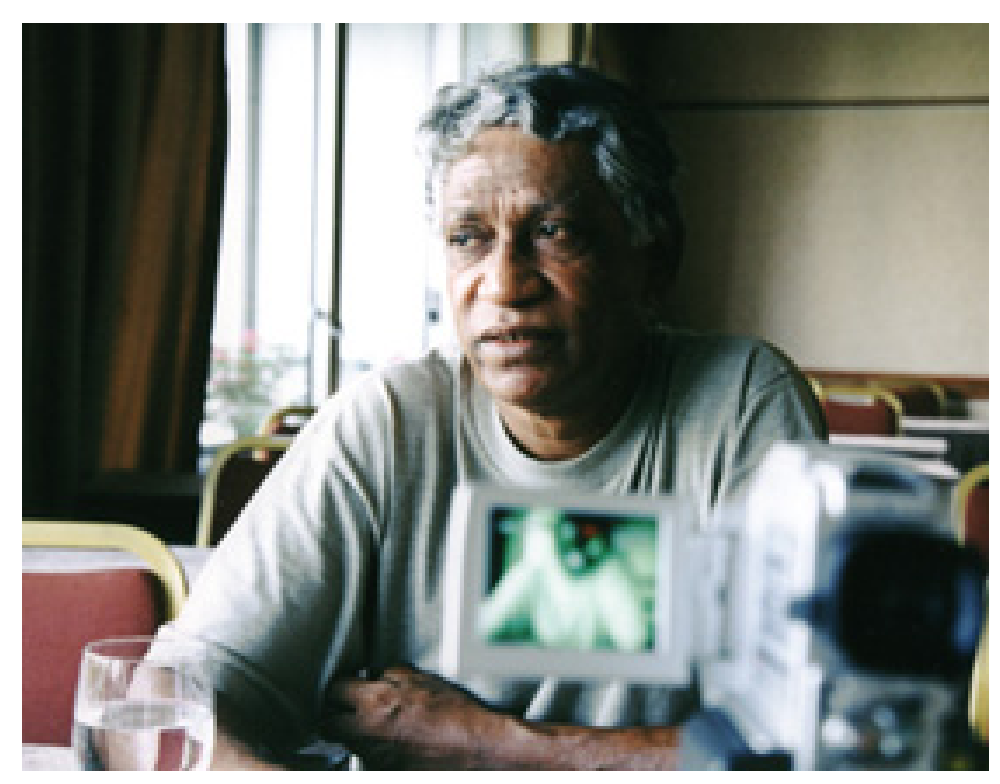

Figure 1: Dharmasena Pathiraja

\section{References}

\section{Dharmasena Pathiraja filmography}

\section{Features}

One League Of Sky (Ahas Gawwa, b/w, 1974)

Coming Of Age (Eya Den Loku Lamayek, b/w, 1975)

Ponmani (b/w, 1977)

The Wasps Are Here (Bambaru Avith, b/w, 1977)

On The Run (Paradige, b/w, 1980)

Old Soldier (Soldadu Unnehe, b/w, 1981)

Whirl Wind (Vasuli, colour, 1994)

Some Day In The Future (Mathu Yam Davasa, colour, 2001)

\section{Documentaries and Shorts}

Enemies (Sathuro, b/w, 1969)

From Darkness To Light (Anduren Eliyata, b/w, 1972)

The Coast (Werala, colour, 1974)

Shelter For Million Families (colour, 1988)

\section{Author Information}

Brandon WEE lives in Toronto. He has written for Asia Pacific Arts (Los Angeles), Cineaste (New York), Cinema Scope (Toronto), Ricepaper (Vancouver), and Senses of Cinema (Melbourne). 